\title{
State Funding of Registered Faith Communities: Discussing Democratic Values in Sweden
}

Liselotte Frisk*

\begin{abstract}
<Abstract>
In this article, the premises for state support of religious communities in Sweden are discussed in relation to democratic values. Registered faith communities in Sweden have the possibility to apply for financial support from the state, as well as for help to collect the membership fee through the state tax payment process. One of the most important criteria to receive state support is that the faith community should contribute to the maintenance and strengthening of the fundamental values of society, the state funding opportunity thus being intimately related to the Swedish conception of democracy. In 2016, 43 faith communities were receiving economic support from the state on these premises. Some applications for state funding of religious faith communities have, however, been turned down. This article will focus on one of these cases, the application from Jehovah's Witnesses, which has been turned down on the critique that the faith community does not contribute to the maintenance and strengthening of the fundamental values of society. This case has been in question since 2007 and is still not resolved. Based on this case, the question of fundamental values of society, a corner stone in the Swedish perspective on democracy, will be problematized, and some dilemmas will be pinpointed.
\end{abstract}

[Keywords] Registered faith communities, state support, Jehovah's Witnesses, fundamental values of society

\footnotetext{
* *Frisk, Liselotte (Email: Ifi@du.se)

Ph.D. earned: Åbo Akademi University, Finland

Affiliation: Professor of Religious Studies, Dalarna University, Falum and Borlänge, Sweden

Received: 20 January 2018; Approved: 27 May 2018
} 


\section{등록된 신앙 공동체의 국가 재정지원: \\ 스웨덴의 민주적인 가치를 논하면서}

\section{〈국문요약>}

이 논문에서는 스웨덴의 종교 공동체에 대한 국가 지원을 위한 전제 조건을 민주적 가치와 관련하여 논의한다. 스웨덴의 등록된 종교 단체들은 주정부의 재정 지원을 신청할 수 있을 뿐만 아니라 주 세금 납부 절차를 통해 회원비를 징수하는 데 도움을 받을 수 있다. 국가 지원을 받기 위한 가장 중요한 기준 중 하나는 종교 공동체가 사회의 근본적인 가치를 유지하고 강화하는데 기여하고 있느냐 하는 점이다. 그래서 국가지원금을 받을 수 있는 기회는 스웨덴 민주주의의 전망과 친밀하게 연관되어 있다. 2016 년 43 개 종교 단체가 주 정부로부터 경제적 지원을 받았다. 그러나 어떤 종교 단체들의 국가 자금 지원 신청은 거부되었다. 이 논문은 여호와의 증인들이 종교계가 사회의 근본적 가치를 유지하고 강화하는 데 기여하지 않는다는 비판을 거부한 한 사례에 초점을 맞출 것이다. 이 사건은 2007 년부터 문제가 되어 왔고 아직 해결되지 않았다. 이 사건을 토대로 스웨덴의 민주주의적 관점에서 가장 중요한 문제인 사회의 근본적 가치에 대한 문제가 규명될 것이며, 약간의 논쟁점이 제시될 것이다.

[주제어] 등록된 신앙 공동체, 국가 지원, 여호와의 증인, 사회의 근본적 가치
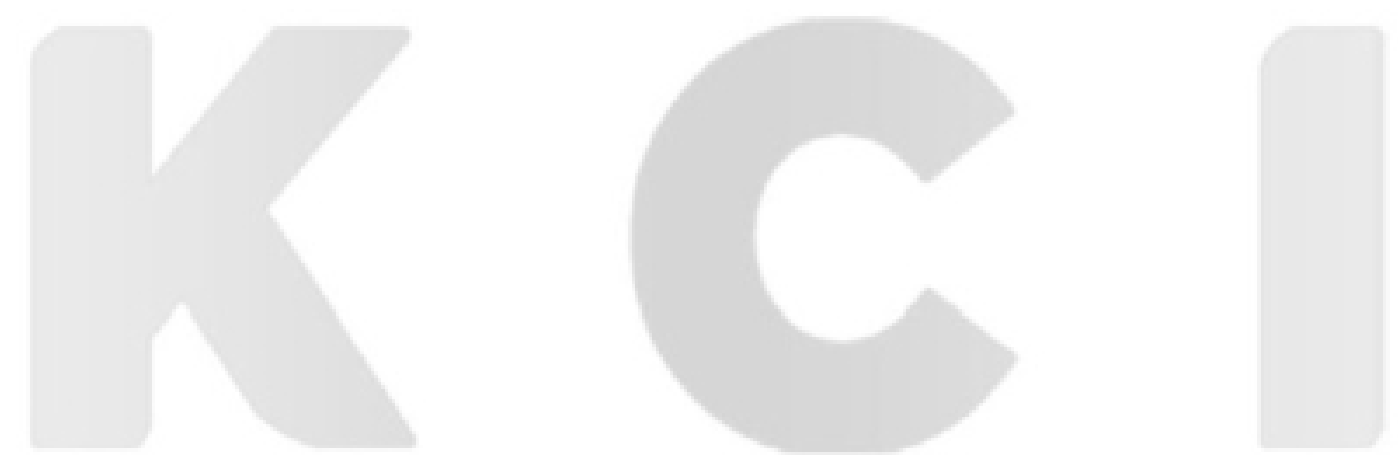


\section{Introduction}

Sweden is known to be one of the most secularized countries in the world. This has, however, not always been the case, and even for contemporary society is a postulation that may be questioned (see for example Frisk and Åkerbäck 2015). From the end of the $16^{\text {th }}$ century until 2000 , Sweden had a state church of Christian Evangelical Lutheran orientation. Until the $19^{\text {th }}$ century, the Church of Sweden was the only church recognized by the state, and its affairs were regulated by the parliament (Church of Sweden 2017a). Religious freedom, in the sense that an individual could disaffiliate himself from the Church of Sweden without joining another recognized church, was not implemented until the year 1952. In 2016 , around $61 \%$ of the Swedish population of approximately 10 million were members of the Church of Sweden. The percentage is, however, constantly decreasing. In 1972, 95\% of the Swedish population had been members. Most of the members are quite passive: on the average, about $2-3 \%$ of the members attend the weekly Sunday service, and this number is also constantly decreasing (Church of Sweden 2017b).

Besides the state church, historically the so-called "free churches," with roots in revivalist currents from the $18^{\text {th }}$ and $19^{\text {th }}$ centuries, have been important in Sweden. There are different ways of counting membership in these churches, but according to one source about $2.2 \%$ of the Swedish population belong to one of the free churches (Tholvsen 2016, 7).
During recent decades immigration to Sweden has increased dramatically, and with immigrants have arrived the religions of the immigrants as well. Especially prominent here is the Muslim faith, which today encompasses a few hundred thousand members in Sweden (Andersson and Sander 2015).

In 2000, however, church and state were separated, and the Church of Sweden became independent from the state. At the same time, a possibility to register as a faith community ("trossamfund") was offered for religious organizations. Registered faith communities could also apply for economic support from the state, as well as for collecting fees from their members through the tax payment process.

This article will study the premises on which economic state support is given and especially focus on one case where the applications have been constantly turned down, on the premise that the religious group does not "support the fundamental values of society." This case concerns the Jehovah's Witnesses, which today has more than 8 million members worldwide, according to the group's own estimation. In Sweden, the membership is around 22,000 (JW.org 2017b). Based on this case, democratic values from the Swedish perspective will be discussed.

The sources used in this article are, first, different documents from the web site of SST, the Office of Government Subsidy to Faith Communities (Nämnden för statligt stöd till trossamfund). This council has the task of distributing the economic support to the faith communities, and is also a consultative body for proposals concerning religion and 
religious communities in Sweden and acts as an expert authority in these matters. It also functions as an expert council for the government in decisions about state funding to faith communities. Second, different law texts, and other official documents such as applications and legal decisions, are used. The analysis also references a book published by SST in 2006, which discussed the premises of the state support from the perspective of several authors.

\section{Economic State Support to Registered Faith Communities}

In 1971, as a result of a bill submitted to the parliament, a possibility for economic state support for the free churches was introduced (Ekström 2006, 11). The model was the Swedish system of economic state support for political parties that was introduced in the 1960s. Based on the premise that it is a democratic value in and of itself to support different views and perspectives, this support for political parties has no ideological borders (SST 2017b).

The reasons for giving faith communities economic support were discussed at that time and later on in different contexts (see for instance Government of Sweden 2017). An important argument involved the usefulness of faith communities to society. Faith communities were taken to contribute to the norm-creating process necessary to strengthen and maintain the fundamental values of society. The case was made that an active denominational life may strengthen the democratic system, and it was seen as important to support the possibilities for ethnic, linguistic, and religious minorities to keep and develop a cultural and denominational life of their own (SST 2017b).

From an option available at the outset only for the free churches, state support was expanded in the 1970s to apply also to Jewish and Catholic congregations, then to Eastern and Orthodox churches as well as, at the end of the decade, to Muslim organizations. Since many of their congregations were small, the Eastern and Orthodox churches joined in one organization to be able to apply, as there was a rule that the congregation had to encompass at least 3,000 members (Ekström 2006, 11-13). There was also a debate about state funding among the free churches at the time, as there was a fear that the economic state support could at some point evolve into restrictive conditions. The question about conditions for economic support for religious organizations has thus been a hot subject from the start (Ekström 2006, 14).

At the time of the separation between church and state in Sweden in 2000, new laws related to religious congregations and economic state support started to apply. Primarily, there was the law offering the possibility to register as a faith community. A faith community was defined as an association for religious activities in which arranging acts of worship (divine services) is included 1 (Acts of 1998). Otherwise, there are no other demands except formal ones, such as stipulations that there has to be a

\footnotetext{
$12 \S$ Med trossamfund avses i denna lag en gemenskap för religiös verksamhet, $i$ vilken det ingår att anordna gudstjänst.
} 
board and a charter with rules of the association. There are also no special advantages with official registration as a faith community, except the possibility to apply for economic state support.

According to the law about regulating economic support to faith communities, eligibility to receive economic state support entails that the faith community (SST 2017c):

1. Contribute to maintain and strengthen the fundamental values of society.

2. Be stable and have operated for at least five years in Sweden.

3. Be organized as a registered faith community or a registered nonprofit organization with its governing body in Sweden and a firm and clear organizational structure.

4. Demonstrating vitality, serving at least 3,000 people in Sweden and operating at several locations in the country; if the community serves fewer than 3,000 people, it should nevertheless be considered to have its own life force if it is part of an internationally active religious community of substantial size, and if the community, together with other organizations within the same religious family, creates an organization for collaboration on the distribution of state subsidies.

5. Be mainly funded by parishioners resident in Sweden.

6. Must own or rent premises for its activities.

\section{Ila. The Fundamental Values of Swedish Society}

Although in the law text there is no further expansion on the meaning of the term "fundamental values," certain legal precedents have been used to interpret it. The government bill (1998/99: 124) stipulated that the activities of the religious community have to be run in such a way that the equal value of all humans is respected, and that the denomination contributes to norms that are in accordance with democratic values. To meet these goals, the denomination has to engage against all kinds of racism and other types of discrimination as well as against violence and brutality. The faith community should also work to develop the conditions for equality between women and men. Furthermore, the community should strive to insure that its members are guided by principles in accordance with fundamental democratic social values.

However, the law also states that it makes no demands on how decisions are taken in the congregation. For example, it explicitly excluded the appointment of priests or comparable figures from democratic decision-making. Similarly, the community's teaching or world view need not arise from a democratic process. What the government bill instead views as important is that the faith community strives that their members take part in the life of society, and that the faith community clearly distances itself from antidemocratic currents in society (Tegnemo 2006, 89-91). 
This is vaguely formulated, and the ambiguities were noted by some of the consultative bodies to which the proposed measure was referred for consideration. The government defended this wording, however, with the explanation that because the values of society are slowly changing over time, they can only be generally formulated. To protect from government overreach (though in a way that introduced additional problems on how to adjudicate the issue), a clause in the government bill stated that any examination or evaluation of the denomination's teaching in relation to the fundamental values of society could not be undertaken (Tegnemo 2006, 89-92).

The legislative preparatory work also referred to the Swedish constitution to clarify what is meant by democratic values. Particularly relevant clauses in the constitution demand a striving against any discrimination on the basis of sex, skin color, national or ethnic origin, language or religious affiliation, handicap, sexual orientation or age, and encourage support for ethnic, language and religious minorities to maintain and develop a cultural and religious life of their own. Also there is little concrete guidance on how to apply or reconcile the standards (Tegnemo 2006, 93-94).

In the Swedish parliament, as well as in the public discourse, debates have centered on allegations that not all faith communities presently enjoying economic support from the state are in fact acting in support of some of the necessary values. Some free churches, for instance, maintain rules that homosexuals living in partnership may not become priests, while the Catholic Church continues to close its priesthood to women (SST 2017b;

Ekström 2006, 20-24).

\section{IIb. Varieties of Economic Support for Faith Communities}

There are basically three forms of economic state support for which faith communities can apply:

1. Organization support

2. Operational support

3. Project support

Operational support may refer to, for example, support for theological university colleges or to formal spiritual roles in medical care, while project support may refer to specified activities to assist in, for example, education activities, security improvements, or building maintenance. In this context, however, we will consider only organization support, which is funding that the faith communities themselves decide how to use. In 2016, there was 91.8 million SEK to distribute in total. Of this sum, 53.5 million SEK was used for organization support distributed among 43 faith communities (SST 2017a). This funding came to around $60-80$ SEK (7-9 euros) per member per year, which is a very limited amount of money. Exactly how much money each faith community receives depends on the number of members served, the number of employees, and the amount of money that the community itself puts into the organization (reinvestment), which has to be at least as large as the state support (SST 2017b).

Besides these three funding possibilities, religious organizations can 
apply for help in collecting membership fees through the ordinary tax process. In 2015, 14 other faith communities joined the Church of Sweden in receiving help to collect membership fees (Hole 2015b)

\section{IIc. The Decision-making Process}

The government makes the decisions regarding which faith communities will receive state funding. However, SST, the expert organ assigned to distribute the economic funding, also has the responsibility to examine whether applications conform with the law (SST 2017d), and therefore has considerable influence on the decisions.

SST consists of nine members and nine proxies. There is also an advisory board of representatives of all faith communities having the right to economic state support. The faith communities that already receive economic support from the state nominate members and proxies to the council. It is therefore quite an inbred procedure: members in SST are nominated by the faith communities already receiving economic state support (Hole 2015a).

\section{IId. Rejections of Applications for Economic Support for} Faith Communities

Over the two decades since the modern system of economic state support for faith communities was established in anticipation of the separation of church and state, several applications have been rejected. The most common reasons cited for rejection have been too few members and too high a level of financing from nonSwedish sources. An application that was rejected in 2006, 2007, 2009 and 2011 came from Humanisterna, an association encouraging secularism and atheism in Sweden (Humanisterna 2017). Underlying the rejection was the argument that, without religious activities in any commonly accepted sense, the association could not meet the threshold definition of a faith community (Government Decision 2011).

Of special interest to us here are two rejections that have cited the applicants' incompatibility with "the fundamental values of society." The first application, from the Church of Scientology, was rejected by the government in 2006 (Government Decision 2006). The Church of Scientology did not apply for financial support, but for help to collect membership fees through the tax payment process. The evaluation by the SST raised several questions regarding the Church of Scientology, having to do with, first, formal issues concerning its finances and governing statutes that led them to query the organization's soundness and stability, and, second, the matter of the Church of Scientology's contribution to maintaining and strengthening the fundamental values of society (SST 2004). After the government turned down the application, the Church of Scientology did not take the case any further.

In this article we will focus on the second case, which began when the Jehovah's Witnesses applied in 2007 to receive economic state funding for organization support. 


\section{The Case of the Jehovah's Witnesses}

The Jehovah's Witnesses, founded by Charles Taze Russell (1852-1916), date back to the 1870s (Holden 2002, 1). Central to Jehovah's Witnesses' teachings, as summarized on the group's website, is a belief in the oneness of God, who is called Jehovah. Jesus is considered to be the son of God, but Jehovah's Witnesses do not believe in the Trinity. They contend that the kingdom of God will soon be realized on Earth, and humans will then be granted eternal life. They also believe that salvation from sin and death is possible through baptism and changes in one's lifestyle (JW.org 2017a). Witnesses' lifestyles are determined by a number of related elements: obedience to Jehovah, conformity to the standards set in the Bible, an awareness that the members are living in a world that they believe is ruled by Satan, a firm belief that they are living at the end of times, and an urgent need to spread the group's message through "witnessing" (Chryssides 2016, 175). Witnesses do not engage in politics, vote in elections, or celebrate holidays like Christmas (105), nor do they celebrate birthdays (JW.org 2017a). Since 1945 they have refused to accept blood transfusions, since blood is considered a source of life sacred to Jehovah (Holden 2002, 28). Members do not socialize significantly with people from outside the congregation (8). They also refuse to participate in military service (26). Major transgressions can lead to "disfellowshipping" and shunning by the congregation (79).

The report from the SST judged that certain characteristics in the Jehovah's Witnesses do not contribute to maintain and strengthen the fundamental values of Swedish society, and the government therefore rejected the application in June 2009, and then a second time in December 2009, after the Jehovah's Witnesses immediately appealed the decision. The Jehovah's Witnesses then appealed to the Supreme Administrative Court in 2011, which reversed the decision, as the reason for the government's action was not considered clear. Again in 2012, the government rejected the application of the Jehovah's Witnesses. Two beliefs and practices of the Witnesses were adduced by the SST and government as failing to meet the criterion of maintaining and strengthening the fundamental values of Swedish society: that Jehovah's Witnesses do not vote in general elections, and that they refuse blood transfusions. In the decision from 2012, the government states that the right to vote in elections must be considered part of the fundamental values of society.

The Jehovah's Witnesses, however, again appealed. In a verbal hearing in 2013, representatives for the Jehovah's Witnesses stated that the political neutrality advocated by Jehovah's Witnesses does not mean that Jehovah's Witnesses put themselves outside society, but simply that they do not have any interest as to how the governing body handles its assignments. Further, it was stated that Jehovah's Witnesses does not work against any governing bodies but submit to them. It was claimed that 
Jehovah's Witnesses strive to create moral values so that people can become a resource to society; that it is up to the individual member to interpret and apply the teachings of the Jehovah's Witnesses; and that there are no controls as to how individual members act regarding this question.

The Jehovah's Witnesses further argued that the decision of the government was flawed, in particular that it violated Articles 9 and 14 of the European Convention on Human Rights and the basic freedoms guaranteed in the European Convention in that, by limiting resources to it, the state was discriminating against the freedom of religious belief and practice of Jehovah's Witnesses. The group cited cases in which, it argued, the government had taken a much more tolerant reading of the law with regard to other faith communities. The Witnesses also argued that voting in general elections is not an obligation in Sweden, and that direct political participation is not the only activity significant for democracy. It is also important to promote positive values and encourage citizens to obey the law, as the Witnesses do.

The Supreme Administrative Court ruled that while the right to vote is indeed a fundamental value of Swedish society, a right is not an obligation. The law cannot be interpreted to mean that a religious community forfeits the opportunity for state funding if it tells its members, without opposing democratic governance, not to vote. The decision of the government was therefore reversed and sent back to the government for a new assessment (Supreme Administrative

Court 2013).

In January 2016, the government again rejected Jehovah's Witnesses application for state funding. The government based its decision on a report from SST, which advised against approval of the application. The SST stated that the Jehovah's Witnesses adhere to "theocratic edicts" which regulate everything in the members' lives, and that there is no space for the members to have their own opinions. Further, SST held that independent thinking is regularly punished, and that members who leave the organization risk ostracism. SST claimed that according to the Jehovah's Witnesses, the political structure of society is a creation of Satan. The SST further contended that many of the Jehovah's Witnesses' rules contravene the UN Convention on the Rights of the Child, which Sweden is bound to take into account as a signatory. Children, it noted, are not encouraged to think critically about their faith. Also, it is claimed that the Child Convention is undermined by the Jehovah's Witnesses' focus on good and evil that leads them to ostracize defectors and thereby split families. The government also contended that the Jehovah's Witnesses' systematic resistance to blood transfusion is especially problematic regarding children. Putting the rights of children to life and health at risk is not compatible with the fundamental values of society.

In September 2016 the Supreme Administrative Court held a verbal hearing. Representatives of the Jehovah's Witnesses on this occasion stated that the government, by not acknowledging that 
the organization supports the fundamental values of society, promotes incorrect assumptions about the congregation and its members, and that the treatment of Jehovah's Witnesses is discriminatory and a serious violation of the law's prohibition to judge the legitimacy of religious teachings. The Jehovah's Witnesses representatives argued that the fact that individual members may choose to not receive blood transfusions does not have an antidemocratic influence on society. In the rare cases where medical doctors insist on blood transfusion for a child in spite of the parents' attitude, parents who are members of the Jehovah's Witnesses will always follow the law and not act to try to stop the blood transfusion.

Once again, in February 2017, the Supreme Administrative Court reversed the decision of the government and sent the case back to the government. The Supreme Administrative Court stated that a faith community is not in conflict with democratic values if it requests its members to act in a way that is consistent with the rights to express opinions and to reject medical care, as long as the community does not urge its members to interfere if society intervenes in cases of children. In the case of the Jehovah's Witnesses, the congregation encourages its members to cooperate with medical care if it is decided that a child needs a blood transfusion. Therefore, this religious teaching cannot be used as a justification for denying state funding. The majority voted to repeal the government's decision, with one member of the Court dissenting on the grounds that the equal right of all to medical care is a fundamental value of Swedish society, and that the Jehovah's
Witnesses' attitude to blood transfusion for children conflicts with that value (is in conflict with that value. The opinion of this member was, however, overruled (Supreme Administrative Court 2017).

The case is therefore back with the government again, with no outcome so far as of this writing (January 2018).

\section{Discussion}

We will now turn to the implications for democratic values in Sweden from the government's rejection of the application for state funding from Jehovah's Witnesses. First, the Swedish perspective on democracy in relation to the rejection will be outlined in the context of the state report A Sustainable Democracy! Politics for People's Government in the 21st century (Government of Sweden 2000). Second, the question of "equal values", which is fundamental for democracy, will be discussed. Third, "participation in society" as a democratic value will be scrutinized.

\section{IVa. Democracy - The Swedish Perspective}

The question of "fundamental values of society" is certainly complex, with the meanings of the phrase varying both historically and culturally. In the Swedish case, the formulation of fundamental values of society is intrinsically related to the Swedish perspective on democracy. In the state report from 2000 (Government of Sweden 2000) it is declared that citizenship consists of three qualities: participation, influence, and belonging (deltagande, inflytande, delaktighet). The 
report assumes that the greater the extent to which citizens experience access to influence and view themselves as part of society, the higher the probability that they will want to participate, with broad and deep participation to solve common concerns considered crucial for the society (I, 33). Only through active participation can citizens develop fundamental qualities, called "citizen virtues," exemplified by mutual respect and tolerance towards opponents, also described as "sublimation of primitive instincts". Thus, the state report considers it crucial that each citizen participate on different levels to solve common societal concerns, a participation which could be professed not only politically but also in school or in non-profit associations. The state should thus encourage the different forms of participation in social life that are considered meaningful by the citizens themselves (I, 33-34). The idea that the state should provide support for political and religious associations derives from this belief that participation will foster a democratic sense and the desired citizen virtues.

There are, however, some dilemmas with this perspective. One of them is intrinsically related to pluralism. Implicit in the decision to grant state funding to faith communities contributing to maintain and strengthen the fundamental values of society is the assumption that pluralism ethnically, linguistically, and religiously is valuable in itself and contributes to a sound and constructive society. Likewise, another tacit implication is that religious organizations usually stand up for norms and values which are considered valuable in society. However, pluralism can, probably inevitably and necessarily, also include individuals and groups supporting norms and values that may radically differ from mainstream norms and values. It is clear that mutual respect and tolerance towards opponents, qualities held out in the state report as important in a sustainable democracy, have boundaries. Everything cannot be tolerated.

The difficult yet crucial question is to judge exactly where these boundaries should be inscribed in a democratic society, one of the hallmarks of which is also to encompass individuals' freedom of opinion and affirm their right to individual choices and religious freedom. Relatively easy cases to adjudicate include groups using violence (e.g., terrorist organizations), as they desire to perform acts that violate both the law and the social contract. More difficult cases do, however, involve groups like Jehovah's Witnesses, which are far from criminal but hold values different from mainstream society. Moreover, in a secular society religious norms and values may in themselves be incomprehensible, as they lack a secular rationale. The argument that God's viewpoint does not allow his followers to undergo blood transfusions simply makes no sense in a secular context. To consider this perspective as in itself antidemocratic, though, is more difficult to justify, as the government has learned in its unsuccessful efforts to convince the Supreme Administrative Court on this point.

Second, in religious contexts democratic structures do not always fit securely with religion, the content of which is often considered to have been in some sense revealed - also a notion not readily 
comprehensible in a secular culture. The influence of the free churches on the government bill about state funding and fundamental values of society is reflected in the statement that no examination or evaluation of the denomination's teaching in relation to the fundamental values of society may be executed. They (and others) have also benefited from the stipulation that the decision process regarding church teaching or appointment of clergy does not need to be democratic. These statements are clearly a compromise to encompass the needs of the free churches and the ways that many religions work in practice. The compromise, however, increases the degree of difficulty in determining whether a faith community contributes to maintaining and strengthening democratic values. As no examination of the teaching or decision making is allowed, it is not clear how the evaluation is meant to take place, and exactly what is to be evaluated.

\section{IVb. Equal Values as Crucial to Democracy}

Fundamental for the democratic perspective according to the state report about a sustainable democracy is the equal value of all human beings (Government of Sweden 2000, I, 19). In the government bill (1998/99:124) there are certain guidelines as to how "the fundamental values of society" should be understood in the contemporary Swedish context. Two criteria are especially emphasized, race equality and gender equality, but the text also refers to the Constitution, where additional prominence is accorded equality in religious affiliation, sexual orientation, and age.

Significantly, the SST and the government do not choose to discuss the characteristic of the Jehovah's Witnesses that would most clearly connote a failure to contribute to the fundamental values of society as defined in these guidelines. Among the Jehovah's Witnesses females cannot serve in any roles of authority in the congregation and are seen as subordinate to men, while homosexuality is not allowed. These attitudes and actions if taken within other segments of society would be considered to violate equality by gender and sexual orientation. However, similar positions are held by some faith communities already enjoying state support, and therefore could not be offered as a critique of the Jehovah's Witnesses. It is clear that the SST is viewing the issue from the perspective of the free churches and mainline religions, pointing out elements in Jehovah's Witnesses practice that differ from their own while ignoring potential problem points where they share views with the Witnesses that are otherwise considered outside the society's "fundamental values."

\section{IVc. Democracy and Participation in Society}

As we have seen, a cornerstone in the Swedish conception of democracy is the belief in each citizen's active participation to solve common concerns in society. The case of Jehovah's Witnesses, however, shows that this assumption is not valid for everyone. Members of Jehovah's Witnesses will not vote in general elections, not because they do not have 
the access to influence society, but because they believe that God does not want them to. This, of course, reflects the fact that Jehovah's Witnesses members identify with their own subgroup rather than with society at large. This choice can be considered a dilemma for any democratic society: to what extent should society allow for identification with subgroups at the expense of identification with society as a whole? At the same time, religious freedom is also crucial for democracy.

Jehovah's Witnesses argue that participation in political activities is not the only activity significant for democracy. They consider promoting moral values and encouraging citizens to obey the laws as important contributions, and point out that they do not work against governing bodies but submit to them. This approach points out a lacuna in the 2000 state report with regard to sustainable democracy: is it possible for an individual to work for the common concerns in society through vigorous support of certain moral values?

As to political participation, the Supreme Administrative Court has clearly indicated that while voting is incontestably a right, as long as a faith community that warns against exercising the right does not oppose democratic governance, it should not be considered as acting against the fundamental values of society.

\section{Reflections}

\section{Reflections}

It is clear that SST (and thereby the government, which relies heavily on its expert counsel) continues to resist acknowledging Jehovah's Witnesses as eligible for state funding. The matter rests again with the government, after being sent back once more from the Supreme Administrative Court. It is also obvious that the SST views the matter from the perspective of its membership drawn from the free churches and mainline religions, in the way it selectively points out elements in Jehovah's Witnesses theology that differ from their own. Not mentioned are the characteristics of the Jehovah's Witnesses that could most accurately be described as failing to contribute to the fundamental values of society as laid out in the law and constitution, presumably because the same could be said of the views of some of the faith communities already enjoying state support: the extent to which their beliefs and practices contravene a commitment to the equal value of all humans, specified as gender equality and equality of sexual orientation.

The difficulties with the present system of state funding to faith communities in Sweden are evident, and the system has been questioned from many sources. Recently (Government of Sweden 2016) the government decided to investigate the state support to faith communities, with a report due in March 2018. One goal is to suggest clear criteria for a democracy that are compatible with freedom of religion. It is thus probable that the rules for state support may change in the near future. Jehovah's Witnesses are still waiting for a final decision in this matter, and we will thus see what the new rules may mean for their application.

Presumably, the application, from the point of view of Jehovah's Witnesses, is 
not so much about money as about

gaining mainstream status as an acknowledged faith community. Against the background of Jehovah's Witnesses' recent problems in Russia, this question probably has a high priority for the organization.

The "fundamental values of society" what the concept may mean, the ways (if any) in which religious organizations may contribute to them, and therefore the resulting significance of religious organizations for a democratic society remains, however, an open question. The contributions of religion to social cohesion - and conflict - are issues about which important negotiations will undoubtedly continue and intensify as Swedish society becomes more pluralistic and multicultural. 


\section{References}

Acts of 1998. Lag 1998: 1593 om trossamfund.

http://www.notisum.se/rnp/SLS/LAG/1 9981593.HTM. Accessed 27 October 2017.

Andersson, Daniel and Åke Sander, eds. 2015. Det mångreligiösa Sverige - ett landskap i förändring. Stockholm: Studentlitteratur.

Chryssides, George D. 2016. Jehovah's Witnesses: Continuity and Change. Farnham and Burlington: Ashgate Publishing.

Church of Sweden. 2017a. https://www.svenskakyrkan.se/churchand-state. Accessed 27 October 2017.

2017b.

https://www.svenskakyrkan.se/statistik. Accessed 27 October 2017.

Ekström, Sören. 2006. "Staten, trossamfunden och samhällets grundläggande värderingar - en bakgrund." Samfunden och bidragen, 11-35. SST: Proprius.

Frisk, Liselotte and Peter Åkerbäck. 2015. New Religiosity in Contemporary Sweden: The Dalarna Study in National and International Context. London: Equinox.

Government Decision. 2006. Regeringsbeslut U205/327/Kr, Regeringen, Utbildnings- och kulturdepartementet, 16 February 2006.

2011. Regeringsbeslut IV:49, S2011/684/PBB, Regeringen, Socialdepartementet, 27 October 2011. Government of Sweden. 2000. En uthållig demokrati! Politik för folkstyrelse på 2000-talet. https://www.regeringen.se/contentasse ts/69008696fa114a81837274bbf62379 3b/en-uthallig-demokrati---politik-forfolkstyrelse-pa-2000-talet, SOU 2000:1.

2016.

http://www.regeringen.se/rattsdokume nt/kommittedirektiv/2016/06/dir.201662/.

2017. "Staten och trossamfunden - stöd, medverkan inom totalförsvaret," $\mathrm{mm}$. 1998/99: 124. http://www.regeringen.se/49bb8e/cont entassets/d0d5c8d85332474fa848b83 8c28da997/staten-och-trossamfunden--stod-medverkan-inom-totalforsvaretm.m. Accessed 27 October 2017.

Holden, Andrew. 2002 Jehovah's Witnesses: Portrait of a Contemporary Religious Movement. London and New York: Routledge.

Hole, Åsa. 2015a. Email to the author, SST, July 29, 2015.

2015b. Email to the author, SST, August 4, 2015.

Humanisterna.

2017. http://humanisterna.se/. Accessed 27 October 2017.

JW.org. $2017 a$. https://www.jw.org/sv/jehovasvittnen/faq/jehovas-vittnens-trop\%C3\%A5/. Accessed 27 October 2017.

2017b.

https://www.jw.org/sv/publikationer/b\% C3\%B6cker/Jehovas-vittnens-

\%C3\%A5rsbok-2016/. Accessed 27 October 2017.

SST. 2004. SST, Ku 2003/2162/Kr, Yttrande över ansökan av Scientologikyrkan i Sverige om godkännande som trossamfund som får hjälp med 
uppbörd av avgift till trossamfund, 27 August 2004.

\footnotetext{
http://www.sst.a.se/bidrag/utbetaladebi drag.4.49955727139d0ce5f5dbda2.ht ml. Accessed 27 October 2017.
}

http://www.sst.a.se/download/18.3e8d 58c211f8378233080009349/13771884 26475/Rapport2+2009\%2C+uppf\%C3 \%B6ljning+av+statsbidrag.pdf.

Accessed 27 October 2017. 2017c. http://www.sst.a.se/regelverk/tidigarefo reskrifter/tillampningsforeskrifterfromjul i2015.4.6360556114d1ca6b2ff1807c.h tml. Accessed 27 October 2017.

2017d.

http://www.sst.a.se/uppdrag.4.15272bf d13b817fbae13000.html. Accessed 27 October 2017.

Supreme Administrative Court. 2013. Högsta förvaltningsdomstolens dom mål nr 4496-12, November 8, 2013, http://www.hogstaforvaltningsdomstole n.se/Domstolar/regeringsratten/Avg\%c 3\%b6randen/2013/November/449612.pdf.

- $2017 . \quad$ Högsta förvaltningsdomstolens dom, mål $\mathrm{nr}$ 2310-16, Stockholm February 20, 2017.

Tegnemo, Annette. 2006. "'Samhällets grundläggande värderingar ' - om förutsättningarna för statsbidrag till trossamfund." Samfunden och bidragen, 89-110. SST: Proprius.

Tholvsen, Oivind. 2016. "Frikyrkokartan ritas om. En rapport om frikyrkornas utveckling i Sverige 2000-2015." http://www.efk.se/frikyrkokartan. 